\title{
Helicobacter pylori (H.p.) Infection: A possible cause of Chronic Idiopathic Urticaria (Prevalence and Effectiveness of Eradication)
}

\author{
Amer Abu El - Enin*, Abd El-Wahab Fathe** Mohamed Khedr*** and \\ Alaa Abu El-Ata**** \\ Departments of Dermatology and Venereology*, Endemic diseases** Clinical \\ pathology $* * *$ and Microbiology $* * * *$ Faculty of Medicine- Al-Azhar University.
}

\begin{abstract}
:
Chronic idiopathic urticaria (CIU) is one of the most frequent skin diseases with an incidence ranging from $1.2 \%$ to $23 \%$, however its causes remains unknown in the vast majority of cases. A possible relationship between chronic urticaria and Helicobacter pylori (H.p.) has been recently suggested.

The aim of this study was to determine the prevalence of Helicobacter pylori(H.P.) infection in patients with C.I.U. and to investigates the effectiveness of eradication therapy of (H.p.) infection on this skin disease.

100 patients (40 males and 60 females) with C.I.U as well as 45 apparently healthy (age, sex, matched controls) were enrolled in this study underwent serological testing for H.pylori infection with the 13C -urea test as well as by specific IgG antibodies against the H. pylori (ELISA technique). Positive patients were treated with, Omeprazole - Clarithromycin + Amoxicillin for 10 days. Eradication and clinical course were followed up two months after the treatment in comparison to the negative cases as a control group. The clinical evaluation and follow up were demonstrated as worse,. same, less and disappearance of flares.

In our results there was significant difference in the sero prevalence of H.pylori infection between idiopathic chronic urticaria patients and healthy subjects. H.pylori was detected in $75 \%$ of patients and $20 \%$ of controls. Out of 75 patients treated, only 24 showed complete remission of their urticaria after successfully eradicating H.pylori infection ,the others only having some improvement in their symptoms.

The mean $\lg G$ titer was $86.8+42.4$ among patients group, where it was $16 .+42.8$ among the control group $(\mathrm{p}<0.05)$.

After treating the positive patients with appropriate antibiotics for 10 days there are a significant decrease of H.P. specific $\operatorname{lgG}$ as compared to the negative cases and also bacterium eradication is associated with a remission of urticarial symptoms. as compared to the negative cases. In conclusion, Helicobacter pylori affects a high percentage of patients with idiopathic chronic urticaria and bacterium eradication was associated with a remission of urticarial symptoms suggesting a possible role of $\mathrm{H}$. pylori in the pathogeneses of this skin disorder.
\end{abstract}

\section{Introduction}

Urticaria is a common disease affecting up to $15-20 \%$ of the population at least once during their life time (Carsten et al., 2000). Chronic urticaria presents with almost daily occurrence of wide spread itchy, recurrent, urticarial wheals with individual lesions lasting less than 24 hours for at least six weeks. Chronic idiopathic urticaria (CIU) is a term used for chronic urticarial patients in which food and drug allergy, urticarial vacuities and physical urticaria have been excluded (Liutu et al., 1998). The etiology of urticaria often remains unknown, it is recognized only in minority of cases, it may be provoked by single or severs simultaneous 
pathogenicfactors (Liutu et al., 1998). Allergic to a wide variety of agents have been suspected, as well as hypersensitivity to food additives or drugs. Infection have been also regarded as possible etiologic factor in urticaria (Grcavcs, 2002). Several infectious agents have been implicated as an etiologic or an exacerbating factor of chronic urticaria, and the treatment of the underlying infections leads to its resolutions.

\section{Patients and methods}

One hundred patients with ICU (40 males and 60 females ) were enrolled into this study . their age range was 20 to 60 years (mean, 44 years ), and the disease duration was between six months and fifteen years (mean, 36 months ). We used 45 age and sex matched unrelated healthy blood donor volunteers (30females and 15 male ) as controls, their age was between 20 and 65 years of age (mean, 45.4 years ) .CIU was diagnosed by history and clinical findings . Patients with CIU of other origin were excluded from the study, including those with focal /systemic infections, atopy food/drug allergy, physical urticaria, autoimmune diseases, and malignancies. All patients were examined for H.pylori infection with $13-\mathrm{C}$ urea breath test $(6,7)$, and for an enzyme-linked immunosorbent assay (ELISA) for specific IgG antibodies against H.pylori $(8,9)$. All patients were well informed about the study . Controls only had serological testing for H.pylori infection at the start of the study to asses the prevalence of H.pylori in the general population .

Patients with positive (H.p.) specific IgG titer ( $\mathbf{n}=\mathbf{7 5}$ out of 100) were treated for 10 days by triple therapy Omeprazole, $20 \mathrm{mg}$ twice daily + clarithromycin, 500 twice daily + amoxicillin $1 \mathrm{gm}$ twice daily for 10 days, then another clinical reevaluation of patients was also done after therapy of (H.P.) infection and the severity of CIU was assessed as worse same less or disappearance of flares. Statistical analysis: Data obtained were collected, tabulated and statistical analyzed. $P$ values of $<0.001$ or less were considered significant.

Scoring was carried out according to the following criteria : (table1)

1. Three or more + ve findings at a mild degree is considered a mild case.

2. Three or more + ve findings at a moderate degree in considered a moderate case.

3. Three or more + ve findings at a sever degree is considered a sever case.

4. Any other variation is considered a moderate case.

\section{Results}

In this study, a significant increase in H.P. specific IgG level was detected in patients with (CIU) in comparison with the control group $75 / 100(75 \%)$ versus 20/45 (44.4\%), $\mathrm{p}<0.001 \quad$ (table 2).

The mean H.P. specific IgG titer in patients was $86.8(+-) 42.4$, while in the control group it was $48.0(+-) 38.87$ $(\mathrm{p}<0.05)$.

1. As regards the clinical features of (CIU), it was found that H.P0 specific $\operatorname{IgG}+$ ve patients were older $(42+8.4$ versus 36 +8.2 \}years, $\mathrm{p}<0.05$ and urticaria lasted for longer duration $30.28 \%$ verses $36.56 \%) \mathrm{p}<0.05$ than H.p. IgG ve patients

2.Also the majority of our chronic urticarial patients were females in the $3^{\text {rd }}$ and $4^{\text {th }}$ decades of life (chart 2).

3. Gastro intestinal symptoms were present in $58(77 \%)$ of our chronic urticaria patients who had an elevated IgG titer and the effect of anti- helicobacter pylori triple therapy on CIU symptoms, shows that $40 \%$ of patients had the same condition while $60 \%$ was less than before the treatment. 
Table (1): Scoring of chronic idiopathic urticaria patients

\begin{tabular}{|l|l|c|c|c|c|c|}
\hline Degree & $\begin{array}{l}\text { No. of } \\
\text { wheals }\end{array}$ & $\begin{array}{c}\text { \% of body } \\
\text { area involved }\end{array}$ & Associated itching & Duration & Angioedema & Score \\
\hline Mild & $1-5$ & $25 \%$ & $\begin{array}{c}\text { Mild doesn't bother } \\
\text { the patient }\end{array}$ & 6 weeks & No & + ve \\
\hline Moderate & $5-10$ & $25-50 \%$ & $\begin{array}{c}\text { Moderate, bothers } \\
\text { the patient }\end{array}$ & $\begin{array}{c}6 \text { weeks }- \\
1 \text { year }\end{array}$ & Slight degree & ++ ve \\
\hline Severe & $>10$ & $>50 \%$ & $\begin{array}{c}\text { Sever, interfering } \\
\text { with daily activity }\end{array}$ & $>1$ year & $\begin{array}{c}\text { Eyelids, lips, } \\
\text { face }\end{array}$ & +++ ve \\
\hline
\end{tabular}

Statistical analysis :Data obtained were collected, tabulated and statistical analyzed.$P$ values of $<$ 0.05 or less were considered significant.

Table 2 : Helicobacter pylori testing in patients with idiopathic chronic urticaria and in control subjects .

\begin{tabular}{|c|c|c|c|c|c|}
\hline \multirow{2}{*}{ Category } & \multicolumn{2}{|c|}{ Urase test } & \multicolumn{2}{|c|}{ IgG } & \multirow{2}{*}{ Total } \\
\cline { 2 - 5 } & $(+)$ & $(-)$ & $(+)$ & $(-)$ & \\
\hline Patients & $87(87 \%)$ & $13(13 \%)$ & $75(75 \%)$ & $25(25 \%)$ & 100 \\
\hline Controls & - & - & $20(444 \%)$ & $23(55.6 \%)$ & 45 \\
\hline
\end{tabular}

Table 3: Comparison between patients with CIU and healthy controls as regards detection of $\mathrm{H}$. pylori specific IgG.

\begin{tabular}{|l|c|c|c|}
\hline Group & Total No. & \multicolumn{2}{c|}{+ ve H.p. specific IgG. } \\
\cline { 3 - 4 } & & No & $\%$ \\
\hline Group I & 100 & 75 & 75 \\
\hline Group II & 45 & 20 & 44.4 \\
\hline$X^{2}$ & \multicolumn{3}{|c|}{$<.64$} \\
\hline P.value & \multicolumn{2}{|c|}{} \\
\hline
\end{tabular}

Table 4: Clinical features of CIU in positive versus negative H.p. specific IgG.

\begin{tabular}{|l|l|l|l|l|}
\hline \multirow{2}{*}{ Feature } & \multicolumn{2}{|l|}{ Patients No=100 } & T. Test & \multirow{2}{*}{ P. value } \\
\cline { 2 - 4 } & $\begin{array}{l}\text { + ve H.p. specific } \\
\text { IgG. (No.75) }\end{array}$ & $\begin{array}{l}\text { ve H.p. specific } \\
\text { IgG. (No.25) }\end{array}$ & \\
\hline Age (mean years) & $42+8.2$ & $34-9.1$ & 3.32 & $<0.05(\mathrm{~S})$ \\
\hline Wheals $>2.4 \mathrm{hs}$ & $60(80 \%)$ & $15(60 \%)$ & 4.12 & $<0.05(\mathrm{~S})$ \\
\hline $\begin{array}{l}\text { Gastrointestinal } \\
\text { symptoms }\end{array}$ & $58(77 \%)$ & $6(24 \%)$ & 4.2 & $<0: 05(\mathrm{~S})$ \\
\hline
\end{tabular}

(S) $=$ significant $=\mathbf{p}<\mathbf{0 . 0 5}$.

Outcome of to urticaria after treatment.

\begin{tabular}{|l|l|l|}
\hline CIU symptoms & No. of cases & $\%$ \\
\hline Same & 40 & 40 \\
\hline Less & 60 & 60 \\
\hline
\end{tabular}




\section{Discussion}

Chronic urticaria is one of the most frequent skin disease and still its etiology is recognized only in a minority of cases (Greaves, 2000).

Recent evidence suggest that most instances of chronic urticaria are autoimmune , and $27 \%$ to $50 \%$ of patients with ICU have been found to have functional auto antibodies directed against the alpha - chain of the high-affinity $\operatorname{IgE}$ receptor or less commonly against IgG. ( Greaves , 2000 ; Valsccchi \& Pigatto, 1998 and Wcdi et al., 1998) Infection especially hidden or overt have been regarded as possible etiologic factor (Juhlin ., 1981).

Some recent studies point to infections due to helicobacter pylori as being of major importance in the pathogenesis of ICU (Esteban Daiulin, 2000 ; Kolibasova et al., 1994 ; Kolibasova Von et al., 1996) and (Bonomigo et al ., 1999). A number of hypotheses have been suggested about why H.pylori infection could induce chronic urticaria, including the induction of inflammatory cytokines and the possible association of H.pylori infection with autoimmune disease (Kolibasova Von et al., 1996) .

Rebera, et al. (1995) first described the role of Helicobacter pylori in chronic idiopathic urticaria (Rebora et al .,1995). As in our study they detected higher prevalence of H.pylori infection in the patients than in the control group, these results are coincident with what was reported by other authors (Kolibasova et al. , 1994 and Kolibasova Von et al., 1996). But in contrast to these results, Bong, do not found any statistically significant difference between patients and controls (Bong., 1999) . This may explained by the fact that this studies were done in countries with a relatively low prevalence of H.pylori infection (30\%to40\%) compared with ours (60 \%). We further investigate the connection between CIU and $\mathrm{H}$. pylori, we treated the 75 patients with positive $\mathrm{H}$. pylori IgG in our study suffering from CIU. In 60 out of 75 patients $(80 \%)$, clinical improvement of the urticaria was found after eradication of $\mathrm{H}$. pylori and decrease in frequency of CIU in most cases in a follow up period of 2 months from the start of treatment. This was in agreement with that of (Wustlich et al., 1999 and Di compli et al., 1998).

A recent study in this particular showed a significant decrease in the typical symptoms of urticaria, such as wheals, erythema, and purities after eradication of H.pylori (Wustlich et al., 1999 and Di compli et al., 1998). The reason behind this phenomenon, however, are unknown, probably an increase in mast cell de granulation, which could be induced by peculiar H.pylori cytotoxic strains, may act as a trigger in subjects with an individual susceptibility to develop urticaria.

These results may suggest that $\mathrm{H}$. pylori has a role in initiating/ or aggravating urticarial lesions and its eradication mostly leads to improvement of the attacks.

Sixty patients $(80 \%$ of infected patients in whom the bacterium was eradicated after therapy ) showed a total or partial remission of urticaria symptoms . Conversely, symptoms improved only in a minority $(20 \%)$ of uninfected patients . Although many of our patients improved after successful eradication of H.Pylori infection , only $35 \%$ showed complete remission of their urticaria. Reduction in frequency of urticaria symptoms and reduction of antihistamine requirement could partly be due to the natural course of the disease .

Although similar results were reached in some studies 18,19 most literature from the west gives remission rates in $95 \%$ to $100 \%$ of patients infected with H.pylori 1517. The discrepancy between these results and ours may be explained by the fact that all these studies were done in countries with a relatively low prevalence of H.pylori infection (30-40\%) compared with ours $(60 \%)$.

The significant association between H. pylori infection and chronic urticaria leading to the suggesting that investigating H.P. infection must be included in the diagnosing management of chronic idiopathic urticaria especially if they not respond well to conventional therapy. 


\section{Références}

1. Greaves M (2000) : Chronic urticaria. J Allergy Clin. lin-muno U05: 664-72.

2. Gasbarrini A, Ponzetlo A, Franches chi F, et al. (1998): Helicobacter pylori infection and extra digestive diseases. Curent opinion in Gastroenterology, 14 (suppl): S 65.

3. Rebora A, Drago F, Parodi A.( 1995) : May Helicobacter pylori be important for Dermatologists? Dermatology, 191(1): 6.

4. Carstcn BJ, Aldo Finzi and Malcom Greaves (2000): Chronic urticaria: diagnostic recommandations. J of Eur Aca Demy of Dermatology and Venereology, 14: 175-180.

5. Greaves MW (1995) : Chronic urticaria. New England J Med, 332: 1767-1772.

6. Liutu M, Kalimo K, Uksila J, et al (1998) : Etiologic aspects of chronic urticaria. Int. J. Dermatol, 1998; 37 (7) : 515.

7. Grcaves MVV (2002): Palhophysiology of chronic urticaria. lui Arch. Allergy Iinmiinol. 127: 3-9.

8. Shiotani A, Okada K, Yanaoka S, Sakuranc M and Matsunaka M (2001) : Bénéficiai eliecl of Helicobacter pylori éradication in dermatologie diseases. Helicobacter, 6: 60-65.

9. Rebora A, Drago F and Parodi A (1995) : May Helicobacter pylori be important for Dermatologists? Dermatology, 191:6-8.

10. Greaves MW (2000) : Urticaria. International Journal of Dermatol. 39 : 446 - 452.

11. Juhlin L (1981) : Récurrent urticaria: A clinical investigation of 330 patients. $\mathrm{Br} \mathrm{J}$ Dermatol, 104: 369-381.

12. Valscchi $R$ and Pigatto $P$ (1998) : Chronic urticaria and Helicobacter pylori. Acla Demi Venereol, 78: 440-442.
13. Wcdi B, Wagner S, Werfcl T, Manns MP and Kapp A (1998): Prévalence of Helicobacter pylori-associated gastritis in chronic urticaria. lut Arch., 14: 175-180.

14. Esteban Daiulin, Isabcl Jimeno/ Alonso and Aman» Gareia-Diez (2000) : Helicobacter pylori and idiopalhic chronic urticaria. International Journal of Dermatology., 39: 446-452.

15. Kolibasova K, Cervenkova D, Hegyi E et al. (1994) : Helicobacler pylori: etiological factor in chronic urticaria. Dermatoscn, 42: 235-236.

16. Kolibasova Von K, Ccrvencova D, llcgy E et al. (1996): Helicobacter pylori infection and chronic urticaria. J Am Acad. Dermatol, 34: 685-686.

17. Bonomigo RR, Leite CS, Bakis L, et al (1999) : Association of Helicobacter pylori and chronic idiopathic urticaria. Rev. Assoc. Med. Bras., 45: 9.

18. Daiiden K, Jiniene/.-Alonso I anda Garda Die/ A (2000) : Helicobacler pylori and idiopathic chronic urticaria. Int $\mathbf{J}$ Dermatol., 39: 446-452

19. 20-Huok-Nikannc J, Varjonen K, Ilarviina RJ and Kosu-ncn TU (2000) : Is Helicobacter pylori infection asso-cialed with chronic urticaria? Acta Dermatol. Venereol., 80: 425-426.

20. Bong RH. (1999): Helicobacter pylori infection and chronic urticaria British association of Dermatologists annual meeting. Edinburgh, Uni Ted KING DOM, 29 June-3 July, Br. J. Dermatol., 14155 : 16.

21. Wustlich S, Brehler R, Luger TA, et al. (1999) : Helicobacter pylori as a possible Bactérial focus of chronic urticaria Dermatology., 198:130.

22. Di campli C, Gasbarrini A, Nucera, E. et al (1998): Bénéficial effects of Helicobacter Pylori éradication on chronic idiopathie urticaria. Dig. Dis Sci., 43: 1226. 


\section{هليوباكتر بابلوري والارتكاريا المزمنة}

د/ عامر أبو العينين د/ عبد الوهاب فتحي د/محمد بسيوني خضر د/ علاء أبو العطاب)

أقسام الأمر اض الجلدية و الأمر اض المتوطنة و الباثولوجية الإكلينيكية و الميكروبيولوجي كلية الطب - جامعة الأزهر لمرون

هليوباكتر ا بايلوري هو السبب الثائع لالتهابات المعدة و القرحة وهي حاليا

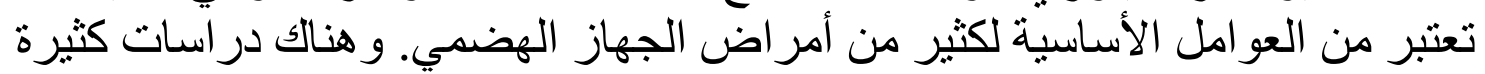











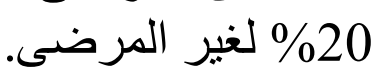

وهو إحصائيا يعتبر معدلا كبير (

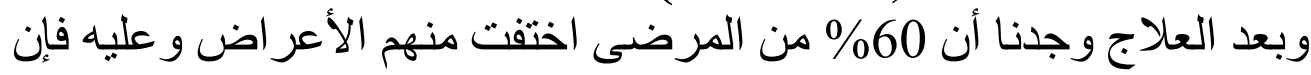

هذه الدر اسة تدعم العلاقة بين الارتكريا المزمنة الغير معروفة السبب العبن والهليوباكتريا يلوري كسبب من الأسباب المحتملة.

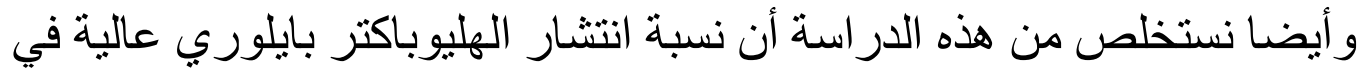

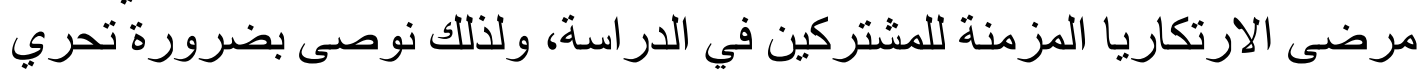

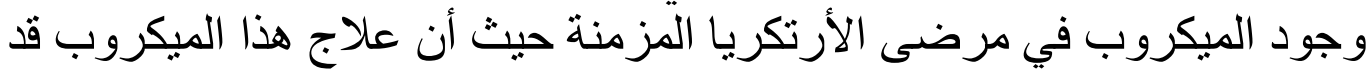
يساعد في شفاء هؤلاء المرضئ. 